\title{
Cytotoxicity Analysis of Crude Leaf Extracts from Tecoma castanifolia (D. Don) Melch on Brine Shrimp and MCF-7 Cell Line
}

\author{
R. Vidhya ${ }^{1}$, Dr. Albin T. Fleming ${ }^{2}$ \\ ${ }^{1,2}$ P.G. \& Research Department of Advanced Zoology \& Biotechnology, Loyola College, Nungambakkam, Chennai-600082, Tamil Nadu, \\ India
}

\begin{abstract}
To assess the possibility of cytotoxic potential of T.castanifolia leaf extract. Since this family of plants have effective cytotoxic potential against cancer, analysis of this particular species was carried out. The acetone, ethylacetate and ethanol extracts were subjected to brine shrimp lethality assay and cytotoxicity analysis against MCF-7 cell line. MTT assay of these three extracts showed the ethyl acetate extract to be most effectively cytotoxic. Further studies can be carried out in this aspect to bring out the complete effectiveness of the extract and compounds therein.
\end{abstract}

Keywords: Plant extract, cytotoxicity, Brine shrimp, MCF-7, MTT assay.

\section{Introduction}

Cancer is one of the leading causes of mortality worldwide and it has been that way since a long time. Worldwide, one in seven deaths is due to cancer; cancer causes more deaths than AIDS, tuberculosis, and malaria combined (American Cancer Society. Global Cancer Facts \& Figures 3rd Edition). Current estimates from the American Cancer Society and from the International Union Against Cancer indicate that 12 million cases of cancer were diagnosed last year, with 7 million deaths worldwide; these numbers are expected to double by 2030 (27 million cases with 17 million deaths) [Aggarwal et al, 2009].Breast cancer is the most commonly diagnosed cancer among women in the vast majority (140 of 184) of countries worldwide, making it the only cancer that is common among women in all regions of the world (IARC CancerBase). There are different types of breast cancer based on the origin of cells from which the tumor has arisen and their point of occurrence. The two major types include ductal and lobular carcinoma and based on their infiltration they can be divided as in situ or invasive. The treatments that are available slow down tumor progression and/or eradicate cancer cells but do not always promise a complete cure with zero relapse and a greater survival period. There has been an increase in research to discover better alternative drugs. The concentration has been on the ethno medicinal plants and their products.

Nature has been a source of medicinal agents for thousands of years and an impressive number of modern drugs have been isolated from natural sources [1]. India is usually referred as "Botanical garden of the world" due to its large diversity in flora. Many traditional medicines in use are derived from medicinal plants, minerals and organic matter [2]. Botanicals are less expensive and easily available because of their natural occurrence in abundance (Opara and Wokocha, 2008). The Bignoniaceae, the bignonias, are a family of flowering plants in the order Lamiales (Vernon $\mathrm{H}$. Heywood et al., (2007)). Bignoniaceae family having 100 genera and more than 800 plant species found in various tropical regions of India.(Kirtikar K.R, 1999). Many species of Bignoniaceae have some use, either commercially or ethno botanically. Several species are known to be used as a folk medicine for diabetes, skin disorders, gastro and urinary disorders etc., (Mohammed Rahmatullah et al, 2010). Tecoma is a genus of 14 species of shrubs or small trees in the trumpet vine family. Tecoma sambucifolia H.B.K. alcoholic extract of flowers also demonstrated cytotoxicity against human hepatoma cell line (Alguacil et al., 2000) [3].One species, T.stans have been known to posses anti diabetic activity and the compounds like tecomine and tecostanin have been isolated from it [4-8]. Based on such literatures, the cytotoxic potential of one of the members of Bignoniaceae, Tecoma castanifolia (D. Don) Melch was analysed in this study.

\section{Materials and Methods}

\section{Materials}

The solvents viz., acetone, ethylacetate and ethanol were of analytical grade and purchased from HiMedia Laboratories Ltd., Mumbai. 3-(4,5-dimethyl thiazol-2-yl)-5-diphenyl tetrazolium bromide (MTT), Foetal Bovine serum (FBS), Phosphate Buffered Saline (PBS), Modified Eagle's Medium (MEM) and Trypsin were obtained from Sigma Aldrich Co, St Louis, USA. EDTA, Glucose and antibiotics from Hi-Media Laboratories Ltd., Mumbai. Dimethyl Sulfoxide (DMSO) and Propanol from E.Merck Ltd., Mumbai, India.

\section{Collection and Extraction of Plant Material}

The leaves of the plant were collected in Chennai and the plant was authenticated from Botanical Survey of India, Coimbatore. The voucher number for the same is BSI/SRC/5/23/2014-15/Tech./842. The leaves were cleaned thoroughly and healthy leaves were shade dried. The dried leaves were then coarsely ground and cold extracted with various solvents for a period of 7 days with continuous shaking. The solvents were changed thrice during the period and filtered through Whatmann No.1 filter paper. It was then rotary evaporated to obtain a gummy extract which were stored in a glass vial. 


\section{International Journal of Science and Research (IJSR) \\ ISSN (Online): 2319-7064}

Index Copernicus Value (2013): 6.14 | Impact Factor (2014): 5.611

Brine Shrimp Lethality Assay

The eggs of Brine shrimp (Artemia salina) were collected from an aquarium shop and hatched in a tank with constant oxygen supply and artificial sea water ( $38 \mathrm{~g}$ sea salt in 1 litre of distilled water). $10 \mathrm{mg}$ of each sample was dissolved in $150 \mu \mathrm{l}$ of DMSO and $1850 \mu \mathrm{l}$ of deionised water. The extracts were tested at various concentrations from $1.25 \mathrm{mg}$, $1 \mathrm{mg}, 0.5 \mathrm{mg}$ up to $0.025 \mathrm{mg}$ by adding respective volume from the stock to a pre marked microtitre plate containing 5 $\mathrm{ml}$ of sea water. All concentrations were tested in triplicates. With the help of a Pasteur pipette 10 living nauplii were transferred to each well. For the next $24 \mathrm{~h}$ the vials were observed and the number of nauplii survived in each vial was counted with the help of magnifying glass $[9,10]$. Potassium dichromate was used as standard cytotoxic agent. (Modified method from Meyer et al., 1982; Zhao et al., 1992). From this, the percentage of lethality of brine shrimp nauplii was calculated for each concentration of the extract. The LC50 value was calculated using probit analysis.

\section{Cell lines and Culture medium}

MCF-7 (Human breast carcinoma) cell line was procured from National Centre for Cell Sciences (NCCS), Pune, India. Stock cells were cultured in MEM supplemented with $10 \%$ inactivated Foetal Bovine Serum (FBS), penicillin (100 $\mathrm{IU} / \mathrm{ml})$, streptomycin $(100 \mu \mathrm{g} / \mathrm{ml})$ and amphotericin B (5 $\mu \mathrm{g} / \mathrm{ml})$ in an humidified atmosphere of $5 \% \mathrm{CO}_{2}$ at $37^{\circ} \mathrm{C}$ until confluent. The cells were dissociated with TPVG solution $(0.2 \%$ trypsin, $0.02 \%$ EDTA, $0.05 \%$ glucose in PBS). The stock cultures were grown in $25 \mathrm{~cm}^{2}$ culture flasks and all experiments were carried out in 96 well microtitre plates (Tarsons India Pvt. Ltd., Kolkata, India).

\section{Preparation of Test Solutions}

For Cytotoxicity studies, each weighed test drugs were separately dissolved in distilled DMSO and volume was made up with MEM supplemented with $2 \%$ inactivated FBS to obtain a stock solution of $1 \mathrm{mg} / \mathrm{ml}$ concentration and sterilized by filtration. Serial two fold dilutions were prepared from this for carrying out cytotoxic studies.

\section{Determination of cell viability by MTT Assay}

The monolayer cell culture was trypsinized and the cell count was adjusted to $1.0 \times 10^{5}$ cells $/ \mathrm{ml}$ using MEM containing $10 \%$ FBS. To each well of the 96 well microtitre plate, $0.1 \mathrm{ml}$ of the diluted cell suspension (approximately 10,000 cells) was added. After $24 \mathrm{~h}$, when a partial monolayer was formed the supernatant was flicked off, the monolayer was washed once with medium and $100 \mu \mathrm{l}$ of different test concentrations of test drugs were added on to the partial monolayer in microtitre plates. The plates were then incubated at $37^{\circ} \mathrm{C}$ for 3 days in $5 \% \mathrm{CO}_{2}$ atmosphere, and microscopic examination was carried out and observations were noted every $24 \mathrm{~h}$ interval. After $72 \mathrm{~h}$, the drug solutions in the wells were discarded and $50 \mu \mathrm{l}$ of MTT in PBS was added to each well. The plates were gently shaken and incubated for $3 \mathrm{~h}$ at $37^{\circ} \mathrm{C}$ in $5 \% \mathrm{CO}_{2}$ atmosphere. The supernatant was removed and $100 \mu \mathrm{l}$ of propanol was added and the plates were gently shaken to solubilize the formed formazan. The absorbance was measured using a microplate reader at a wavelength of 540 $\mathrm{nm}[11,12]$. The percentage growth inhibition was calculated using the following formula

$$
\% \text { Growth Inhibition }=\left(\frac{\text { Mean OD of individual test group }}{\text { Mean OD of control group }} \times 100\right)
$$

\section{Results}

\section{Brine Shrimp Lethality Assay}

The LC50 values calculated for each extract is tabulated in Table 1. Of the three extracts tested the ethyl acetate extract showed very potent activity as compared to the control, Potassium dichromate. The LC50 i.e., 50\% mortality of the test organisms were obtained around $370 \mu \mathrm{g} / \mathrm{ml}$ concentration from ethyl acetate extract.
Table 1: LC50 Values of Brine Shrimp Lethality Assay

\begin{tabular}{|c|c|c|}
\hline S. No & Name of Extract & LC50 \\
\hline 1. & Acetone & $906 \mu \mathrm{g} / \mathrm{ml}$ \\
\hline 2. & EthylAcetate & $370 \mu \mathrm{g} / \mathrm{ml}$ \\
\hline 3. & Ethanol & $1233 \mu \mathrm{g} / \mathrm{ml}$ \\
\hline 4. & Potassium Dichromate & $495 \mu \mathrm{g} / \mathrm{ml}$ \\
\hline
\end{tabular}

\section{MTT Assay}

The three extracts were tested against MCF-7, a breast cancer cell line. The effectiveness of inhibition of the three extracts is graphically represented in Figure1. The GI50 values of acetone, ethyl acetate and ethanol extracts are $>1000 \mu \mathrm{g} / \mathrm{ml}, 335 \mu \mathrm{g} / \mathrm{ml}$ and $926.67 \mu \mathrm{g} / \mathrm{ml}$ respectively. 
International Journal of Science and Research (IJSR)

ISSN (Online): 2319-7064

Index Copernicus Value (2013): 6.14 | Impact Factor (2014): 5.611

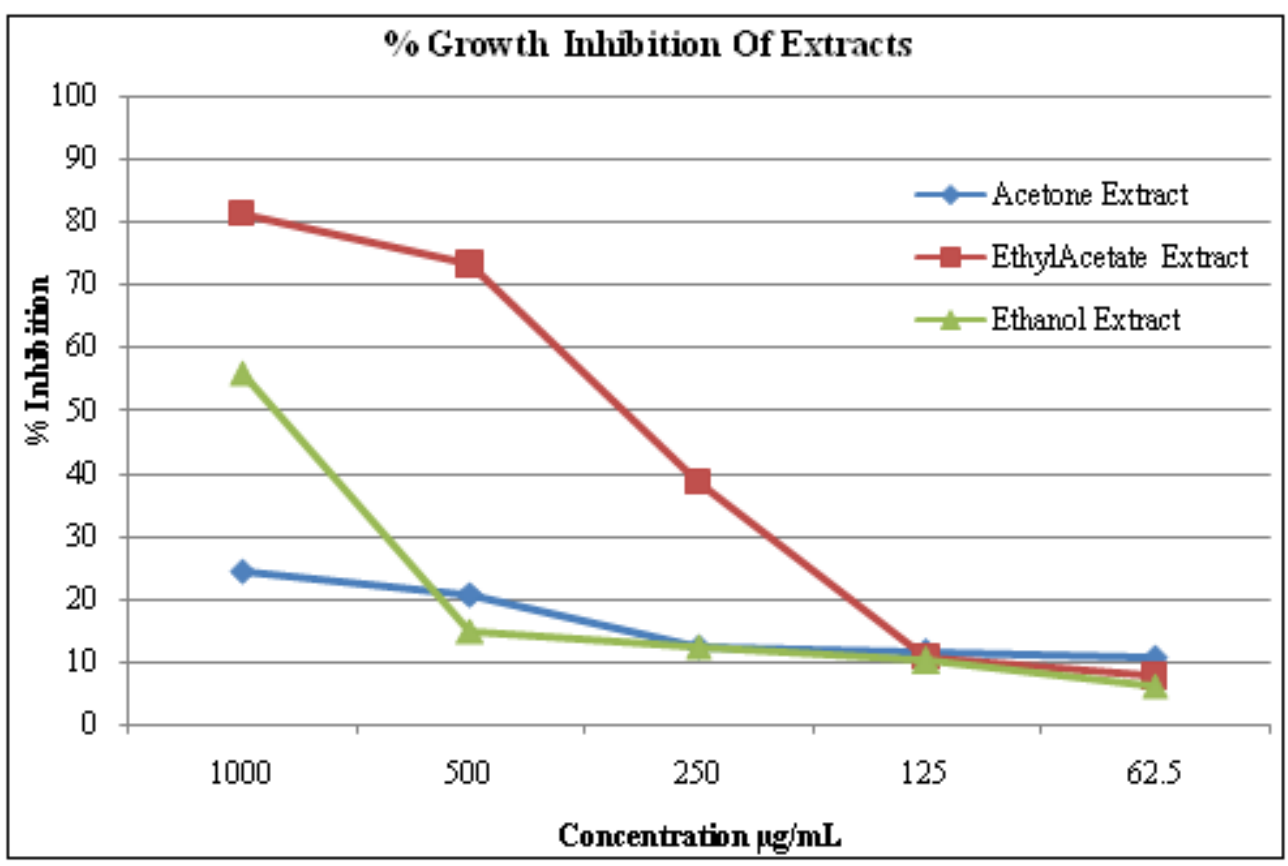

Figure 1: Graphical representation of Cell Growth Inhibition of the Extracts on MCF-7

\section{Discussion}

The genus of Tecoma has been traditionally used in various parts of the world to treat a variety of conditions and cancer is recorded to be one of it. The leaves of the plant is known to contain phenolic acid, beta-setosterol, triterpenoids etc., both phenol and flavonoids possessing antioxidant activity. Tecoma fabrisi and Tecoma impetignosa are used to treat some forms of cancer [13].

The three solvent extracts showed potent cell growth inhibitory activity. This may be due to their action on any one of the following- mitosis, biochemical processes etc. The biological activity shown by plants is mainly due to their secondary metabolites like alkaloids, phenolics, flavonoids, terpenoids, saponins etc. These are referred to as bioactive phyto compounds. Several phytochemical studies revealed that the extracts from many species of Bignoniaceae contained secondary metabolites such as saponins, tannins, flavonoids, quinones, alkaloids, anthralene derivatives, reducing sugars, glycosides, carbohydrates, querletin, kaempferol, â-sitosterol, terpenes, steroids, coumarins etc., and their derivatives [14].

From the above results it is clear that the LC50 values of brine shrimp lethality assay correlates with the GI50 values of the MTT assay. Brine shrimp Lethality assay is becoming a preliminary standard assay to assess the cytotoxic potential of plant extracts. Since many plants both land and marine are being tested for their various potentials, this preliminary assay is best suited to eliminate and/or select plant extracts for further study as a cytotoxic agent.

Out of the three crude plant leaf extracts tested here the ethyl acetate extract showed the effectiveness for further studies as an anti cancer agent. Its efficacy can be due to the fact of synergistic effects of various compounds present in the crude extract. The plants belonging to the family Bignoniaceae are one of the important sources of new bioactive compounds and as such several new chemical entities have been isolated and tested for their efficacy as drugs [14]. The compounds present in the extract must be studied and the reason behind the activity (cell cycle arrest or biochemical interference etc.) should be assessed.

\section{Conclusion}

The study was conducted to assess the possibility of this plant extract to have a potent cytotoxic potential. From the preliminary assay it is clear that this plant can be further studied for its activity as a cytotoxic agent. Further studies into their way of action, phytochemicals involved etc., need to be explored.

\section{References}

[1] DyamavvanahalliLakshmanacharShrisha et al., Bioprospecting of selected medicinal plants for antibacterial activity against some pathogenic bacteria; J. Med. Plant. Res. Vol. 5(17), pp. 4087-4093, 9 September, 2011.

[2] Grover, J.K., Yadav, S., and Vats, V.: Medicinal plants of India with antidiabetic potential. J. Ethnopharmacol., 81, 81-100, 2002.

[3] Mohammed Rahmatullah et al., An Ethnomedicinal, Pharmacological and Phytochemical Review of Some Bignoniaceae Family Plants and a Description of Bignoniaceae Plants in Folk Medicinal Uses in Bangladesh, Adv. in Nat. Appl. Sci., 4(3): 236-253, 2010

[4] S Raju et. al. Tecoma stans (L.) Juss. ex Kunth (Bignoniaceae): Ethnobotany, Phytochemistry and Pharmacology, JPBMS, 2011, 8 (07).

[5] Sing $\mathrm{V}$ et. al., Pharmacological and Phytochemical Findings of Tecoma stans- A Review, JAPHR, 2011, Volume1, Issue 3.

[6] E. HERNANDEZ-GALICIA et al.,Studies on Hypoglycemic Activity of Mexican Medicinal Plants, Proc. West. Pharmacol. Soc. 45: 118-124 (2002).

\section{Volume 4 Issue 12, December 2015}




\section{International Journal of Science and Research (IJSR) \\ ISSN (Online): 2319-7064}

Index Copernicus Value (2013): 6.14 | Impact Factor (2014): 5.611

[7] A.J. Alonso-Castro et al., The antidiabetic plants Tecoma stans (L.) Juss. ex Kunth (Bignoniaceae) and Teucrium cubense Jacq (Lamiaceae) induce the incorporation of glucose in insulin-sensitive and insulinresistant murine and human adipocytes, Journal of Ethnopharmacology 127 (2010) 1-6.

[8] Thirumal et al., invitro anticancer activity of Tecoma stans (L.) ethanolic leaf extract on human breast cancer cell line (MCF-7), IJPCBS 2012, 2(4), 488-493.

[9] Kaniz Fatima Urmi et al., Comparative Brine Shrimp Lethality Bioassay of Different Plant Parts of Bauhinia Purpurea L., J. Pharm. Sci. \& Res. Vol.5(10), 2013, 190 $-192$.

[10] Rumzhum et al., Antioxidant and cytotoxic potential of methanol extract of Tabernaemontana divaricata leaves, International Current Pharmaceutical Journal 2012, 1(2): 27-31.

[11] Pavan Kumar Bellamakondi et al., In vitro Cytotoxicity of caralluma species by MTT and Trypan blue dye exclusion, Asian J Pharm Clin Res, Vol 7, Issue 2, 2014, 17-19.

[12] Patel Janki B et al., Anticancer and Cytotoxic Potential of Triticum aestivum Extract on Hela Cell Line, IRJP 2013, 4 (1).

[13] Swarna Kandakatla., K.N.V Rao., David Banji., EthnoMedicinal Review on "Pachagotla" (Tecoma stans (I.)Juss. Ex kunth), Herbal Tech Industry, November 2010.

[14] Shuvasish Choudhury et al., Phytochemistry of the Family Bignoniaceae- A review Assam University Journal of Science \& Technology : Biological and Environmental Sciences, Vol. 7 Number I; 145-150, 2011.

[15] Renilda Sophy A. J., Albin T. Fleming, Evaluation of Adenanthera pavonina Bark Extracts for Antioxidant Activity and Cytotoxicity against Cancer Cell Lines, IJSR, Volume 4 Issue 12, December 2015.

\section{Author Profile}

Vidhya Rajagopal, Research Scholar, P.G. \& Research Department of Advanced Zoology and Biotechnology, Loyola College, Chennai.

Dr. Albin T. Fleming, Associate Professor, P.G. \& Research Department of Advanced Zoology and Biotechnology, Loyola College, Chennai. 